\title{
Financial Inclusion, Financial Stability and Sustainability in the Banking Sector: The Case of Indonesia
}

\author{
Submitted 25/11/19, 1st revision 29/12/19, 2nd revision 28/01/20, accepted 15/02/20
}

\section{Nera Marinda Machdar ${ }^{1}$}

\begin{abstract}
:
Purpose: The purpose of the present study is to analyze the effect of financial inclusion on sustainable economic growth for Indonesian banking companies, and to investigate the effect of financial inclusion on sustainable economic growth through financial system stability.

Design/Methodology/Approach: This research is a quantitative study using secondary data taken from annual financial statements of banking companies listed on the Indonesia Stock Exchange (BEI) over the period 2010-2017.

Findings: The results show that (a) the financial inclusion does not affect sustainable economic growth in Indonesian banking companies, and (b) the financial system stability mediates the effect of financial inclusion on sustainable economic growth in Indonesian banking companies.

Practical Implications: This study provides deeper insight into the factors that drive financial inclusion and an increase in market share and financial performance of banks. With conditions of inclusion that are still low in Indonesia while the number of banks is increasing, it is necessary to have strong financial system stability. By understanding the matrix in financial inclusion, managers are well-positioned to understand the strategies needed to promote financial inclusion so that market share increases. Likewise, the results of the present study are probable to be an input for other stakeholders for their consideration in decision making.

Originality/Value: Empirical research that explores the effects of financial inclusion, and sustainable economic growth in Indonesia is still very limited. According to our knowledge, no one has examined the use of financial system stability as mediation as it is used in this study.
\end{abstract}

Keywords: Financial inclusion, financial system stability, sustainable economic growth.

JEL Codes: G18, G28, 047.

Paper type: Research article.

\footnotetext{
${ }^{1}$ Associate Professor, Department of Accounting, Faculty of Business, Institut Teknologi dan Bisnis Kalbis, Jalan Pulomas Selatan, Jakarta, Indonesia, Email: nera.marinda@kalbis.ac.id
} 


\section{Introduction}

Today financial inclusion has become an important issue in funding economic development in a capacity as a driver of sustanable economic growth. The leaders of the G20 countries support financial inclusion as the main foundation of global development in 2010. In 2015 the United Nations (UN) introduced a concept of the Sustainable Development Goals (SDGs) which highlighted the role of financial inclusion in achieving common goals that can maintain the balance of three dimensions of sustainable development such as the environment, social and economic. At the international level, financial inclusion was discussed in the OECD, AFI, APEC, World Bank, IMF and ASEAN forums, where Indonesia actively participated. At the national level, the Indonesian government has committed in the Chairman's Statement at the 2011 ASEAN Summit in determining the national financial inclusion strategy.

The financial inclusion program focuses on increasing access to more people who have not yet enjoyed the services of formal financial institutions (Dienillah and Anggraeni, 2016). The circumstance of financial access in Indonesia is still considered low and it is reflected in the low-level of financial inclusion (Setiawan, 2017). This occurs because of a lack of knowledge and understanding of the function of financial institutions and product discrepancies proposed by financial institutions with low-income community needs. Indonesia is a country with a highlevel of financial exclusivity. World Bank results in 2014 showed that Indonesia's financial inclusion was only $36 \%$, which means that of the 100 Indonesian adults, only 36 had accounts in recognized financial organizations.

The global financial crisis resulted in a devastating systemic impact. Financial system stability has turn into a central matter in recent years, particularly afterward the economic disaster. The stability of financial system shows a significant part in the economy. As part of the economic system, the financial scheme functions as an allocation of funds from parties experiencing a surplus to the deficit party (Bank Indonesia, 2014). When the financial system is unstable and does not function efficiently, the allocation of funds is not going well so that it inhibits sustainable economic growth. Successful sustainable economic growth is marked by a stable financial system (Rupeika-Apoga and Saksonova, 2018).

Empirical research that explores the effects of financial inclusion, and sustainable economic growth in Indonesia is still very limited. To our knowledge, no one has examined the use of financial system stability as a mediator of the effects of financial inclusion on sustainable economic growth. Therefore, this study tries to analyze whether (a) financial inclusion affects sustainable economic growth and (b) financial system stability mediates the effect of financial inclusion on sustainable economic growth in Indonesian banking companies. The results of the study make additional theoretical contributions to researchers and academics in the future. Besides, it provides input for policymakers in the macroeconomic policy. In detail, 
regulatory power would not only develop financial inclusion hard work through increased lending to the private segment but must also reinforce the regulatory agenda to certify efficient and effective sharing out and exploitation of resources.

Furthermore, it provides benefits for banking practitioners, especially for managers of financial institutions. This study provides deeper insight into the factors that drive financial inclusion so that there is an increase in market share and financial performance of banks. With the conditions of inclusion that are still low in Indonesia while the number of banks is increasing, it is necessary to have strong financial system stability. By understanding the matrix in financial inclusion, managers are well-positioned to understand the strategies needed to promote financial inclusion so the market share will increase. Likewise, the results of the present study are probable to be an input for other stakeholders for their consideration in decision making.

\section{Literature Review}

Bank Indonesia (2014) defines financial inclusion as an attempt to eliminate all practices of price and non-price barriers to public admittance in using financial facilities. Financial inclusion is an effort to apply financial service rules by eliminating all forms of perception to all society that provides benefits at a fair price, the right practice, and the appropriate time (Aduda and Kalunda, 2012). As stated by Allen, Demirguc-Kunt, Klapper, Soleda, and Peria (2016), financial inclusion provides easy access to financial facilities such as savings, credit, payments, pension funds, and other products. This has greatly helped marginalized low-income groups to improve their welfare. Hannig and Jansen (2010) state that financial inclusion is an effort to encourage people who do not have bank account into the formal financial system to get financial products. Products available include savings, credit, payments, insurance, money transfers, and investments, for the served and unserved segments of different markets (Operaña, 2016). Financial inclusion is a very important tool to lessen poverty and income inequality in efforts to increase access of the poor to financial services (Williams, Adegoke and Dare, 2017).

Sustainable economic growth is proxy by the gross domestic product as an indicator to see the total income earned by the community in the economy of a country, and also to assess the level of welfare of the community. So the higher the growth level of a country's gross domestic product, the higher the welfare's community in the country (Solovjova and Rupeika-Apoga, 2018). Economic growth is a procedure of increasing overall income by considering population growth and fundamental changes in the economic structure of a country (Baroroh, 2012).

Gour'ene and Mendy (2017) show that there is no causality between economic growth and financial inclusion indicators on a scale of 2-4 years in Senegal. However, two-way causality were found between economic growth and financial inclusion on a scale of 4-8 years. Okoye, Adetiloye, Erin and Modebe (2017) concludes the findings in Nigeria as: (i) financial inclusion index does not influence 
economic growth (ii) financial inclusion has driven poverty lessening through granting rural credit. Nkwede (2015) states that Nigeria's economic growth is severely disrupted due to the unavailability of banking and financial services, lack of access to banking and financial services and the lack of utilization of banking and financial services. Conditions of the level of financial inclusion in Indonesia are similar to conditions in Senegal and Nigeria. Therefore, the study proposes the first hypothesis as follows:

\section{H1: Financial inclusion does not affect sustainable economic growth.}

The global financial crisis has focused attention on financial system stability. From a broader perspective, this condition reflects the occurrence of a stable financial system, so that it can allocate sources of funds, absorb shocks that occur, and resist disruption to real sector activities and the financial system (Bank Indonesia, 2014). Financial system stability is reflected in a financial system that is strong and resistant to various economic disturbances so that it is still able to perform the intermediation function, carry out payments and spread risk properly. A stable financial system reflects a financial system that can cope with shocks and reduce barriers in the financial intermediation process (European Central Bank, 2012). Financial system instability can be triggered by various causes and shocks that originate from external (international) and internal (domestic).

Dienillah \& Anggraeni (2016) found that financial inclusion has a positive relationship with the stability of the financial system, which was marked by a decrease in non-performing loans. Moreover, an increase in financial inclusion is followed by a decline in the financial distress. The increased portion of the credit for SMEs helps the stability of the financial system. It is regarded with decreasing nonperforming loans, especially reducing poor loans and the possibility of failing financial institutions (Morgan \& Pontines, 2014). Furthermore, high GDP per capita tends to increase the stability of the financial system, while high private bank credit ratios to GDP reduce the stability of financial system (Rupeika-Apoga et al., 2018).

According to Hannig and Jansen (2010) financial inclusion in addition to addressing income inequality has the potential to increase the stability of the financial system. The more access the poor have to savings from formal financial institutions, the better the capacity of households to manage financial vulnerability due to the adverse effects of the crisis. In addition, it can also diversify funding of financial institutions to reduce shocks when the global crisis occurs. Furthermore, financial inclusion can increase economic resilience by lessening poverty, and accelerating growth. The greater the financial inclusion, the greater the opportunity to improve financial system stability. Creel, Hubert and Labondance (2013) posit that financial instability has a negative effect on economic growth. Manu, Adjasi, Abor and Harvey (2011) emphasized that financial stability drives economic growth. In particular, an important element driving economic growth is the adequacy of capital and liquidity in the financial sector. The high capital adequacy helps banks from the 
possibility of bankruptcy through the absorption of losses that may arise due to the emergence of moral hazard and the high risk taken. In terms of capital adequacy, increased liquidity drives growth in economic activity in the sense that investors have easy access to funds for productive intention.

This study considers that financial inclusion has no direct effect on sustainable economic growth, but has an indirect effect, that is from financial inclusion to sustainable economic growth through financial system stability. Based on the explanation above, the following hypothesis is proposed:

H2: Financial system stability mediates the impact of financial inclusion on sustainable economic growth.

H2(a): Financial system stability measured by financial distress mediates the effect of financial inclusion on sustainable economic growth.

H2(b): Financial system stability measured by non-performing loans mediates the effect of financial inclusion on sustainable economic growth.

\section{Methodology}

This research is a quantitative study using secondary data taken from annual financial statements of banking companies listed in the Indonesia Stock Exchange (BEI) over 2010-2017. Data were obtained from the website https://www.idx.co.id. and https://www.bi.go.id. The sample consisted of 30 commercial banks with 240 observations. Financial inclusion utilizes a third-party fund consisting of savings, current accounts and deposits in commercial banks. Third-party funds are calculated by dividing total third-party funds by gross domestic product (GDP) (Chen, Feng and Wang, 2018). Sustainable economic growth is measured by gross domestic product (GDP) based on constant prices. Financial system stability is measured by financial distress (ZSCORE) and non-performing loans (NPL). Financial distress for the banking sector uses the following formula of Morgan and Pontines (2014):

$$
\mathrm{ZSCORE}_{\mathrm{yn}}=6.56 \mathrm{X}_{1 \mathrm{yn}}+3.26 \mathrm{X}_{2 \mathrm{yn}}+6.72 \mathrm{X}_{3 \mathrm{yn}}+1.05 \mathrm{X}_{4 \mathrm{yn}}
$$

Notes: The criteria for discrimination areas are as follows:

1) $Z>2.6$ is a safety zone, 2) $1.1<Z<2.6$ is gray zone, and 3 ) $Z<1.1$ is bankrupt zone.

$\mathrm{ZSCORE}_{\mathrm{yn}}=\mathrm{Z}$ score index of bank y in year $\mathrm{n}$

$\mathrm{X}_{1 \mathrm{n}}=$ (Current assets-current liabilities) bank $\mathrm{y}$ in year $\mathrm{n} /$ total assets of bank $\mathrm{y}$ in year $\mathrm{n}$

$\mathrm{X}_{2 \mathrm{n}}=$ Retained earnings of bank $\mathrm{y}$ in year $\mathrm{n} /$ total assets of bank $\mathrm{y}$ in year $\mathrm{n}$

$\mathrm{X}_{3 \mathrm{n}}=$ Earnings before interest and tax of bank $\mathrm{y}$ in year $\mathrm{n} /$ total assets of bank $\mathrm{y}$ in year $\mathrm{n}$

$\mathrm{X}_{4 \mathrm{n}}=$ Market value of shares of bank $\mathrm{y}$ in year $\mathrm{n} /$ book value of total debt of bank $\mathrm{y}$ in year $\mathrm{n}$

This study uses inflation and BI rate as control variables. Inflation is a general price increase that occurs continuously in a certain period. Annual inflation is obtained from the average Consumer Price Index (CPI). The BI Rate is an interest rate that 
published monthly by the Board of Governors of Bank Indonesia. This study uses a multiple mediator model, a model developed in the form of macro scripts by Preacher and Hayes (2008). Data analysis in this study is a multiple analysis method using SPSS software. The research model is as follows:

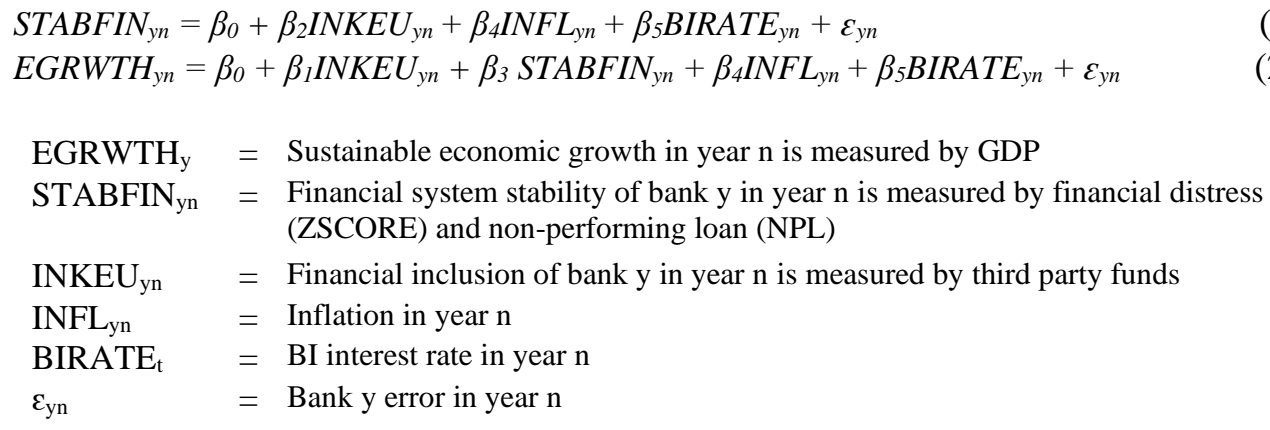

\section{Data Analysis and Results}

This research has conducted a classic assumption test consisting of normality, multicollinearity, heteroscedasticity, and autocorrelation. Table 1 presents the statistical description of the dataset. Sustainable economic growth (ECGWTH), financial system stability is measured by ZSCORE and NPL, inflation (INFL) and BI interest rates (BIRATE) have an average value greater than the standard deviation. This shows that sustainable economic growth, financial system stability, the level of inflation and BI interest rates in most of the samples used are quite varied.

Table 1. Descriptive Statistics

\begin{tabular}{llllll}
\hline & $\mathrm{N}$ & Minimum & Maximum & Mean & Std. Deviation \\
\hline ECGWTH & 240 & 15.74 & 16.11 & 15.93 & 0.12 \\
INKEU & 240 & 0.04 & 85.47 & 10.00 & 16.67 \\
ZSCORE & 228 & -241.61 & 649.30 & 136.65 & 109.10 \\
NPL & 240 & 0.21 & 509.60 & 155.29 & 376.19 \\
INFL & 240 & 3.02 & 8.38 & 5.22 & 2.15 \\
BIRATE & 240 & 4.25 & 7.55 & 6.26 & 1.16 \\
\hline
\end{tabular}

Notes: $E C G W T H=$ Sustainable economic growth, INKEU = Financial inclusion, ZSCORE $=$ Financial system stability measured by financial distress, $N P L=$ Financial system stability measured by non-performing loans, INFL = Inflation rate, and BIRATE $=B I$ interest rates.

Table 2 presents the results of the partial correlation coefficient with the control variable inflation rate and the BI interest rate. The financial inclusion variable (INKEU) has a positive correlation with sustainable economic growth (ECGWTH) of 0.1 , but not statistically significant ( $\mathrm{p}$-value $=0.134)$. The financial system stability variable (ZSCORE) has a positive correlation with sustainable economic growth $($ ECGWTH) of 0.209 being significant at $1 \%$ level (p-value $=0.002$ ). 
Financial stability variable (NPL) has a positive correlation with sustainable economic growth (ECGWTH) of 0.027 , but not significant $(0.682)$. The financial inclusion variable (INKEU) has a positive correlation with financial system stability (ZSCORE) of 0.201 , and is significant at the level of $1 \%(0.002)$. The financial inclusion variable (INKEU) has a negative correlation with financial system stability (NPL) of -0.022 , but it is not significant (0.737).

Table 2. Partial Correlation Coefficient with INFL and BIRATE Control Variables

\begin{tabular}{lllll}
\hline Variable & ECGRTH & INKEU & ZSCORE & NPL \\
\hline ECGWTH & 1.000 & & & \\
INKEU & 0.100 & 1.000 & & \\
p Value & 0.134 & & & \\
ZSCORE & 0.209 & 0.201 & 1.000 & 1.000 \\
p Value & $0.002^{* * *}$ & $0.002^{* * *}$ & & \\
NPL & 0.027 & -0.022 & -0.039 & \\
p Value & 0.682 & 0.737 & 0.561 & \\
\hline
\end{tabular}

Note: Significant at the $10 \%, 5 \%$ and $1 \%$ levels is shown by *), **), ***).

Panel A of Table 3 shows the effect of financial inclusion (INKEU) on financial system stability (ZSCORE and NPL). The effect of INKEU on ZSCORE is markedly positive (0.0716) and significant at significance level $1 \%(0.0024)$. The higher the financial inclusion the higher the financial system stability (the higher ZSCORE value). This can happen because the growth in the number of savers with a small value can also increase the size and stability of the deposit. This can reduce banks' dependence on non-main financing, which is not stable during a crisis. In addition, better monetary policy transmission can also result from greater financial inclusion and this also contributes to financial system stability (Hannig and Jansen, 2010). In addition, Panel A of Table 3 shows that the effect of INKEU on NPL has a negative direction (-0.0276) and is not significant (0.7370). According to Morgan and Pontines (2014) the more increased loans by small and medium-sized companies, the more it improves financial stability, which is characterized by a decrease in non-performing loans and the possibility of further reducing the failure of banking companies.

Panel B of Table 3 presents the effects of financial system stability (ZSCORE and NPL) on sustainable economic growth (ECGRWTH). The effect of ZSCORE on ECGRWTH has a positive direction (0.0023) with a significance level of $1 \%$ (0.0034). The results show that financial system stability which is measured by ZSCORE has a positive effect on sustainable economic growth. Furthermore, Panel $B$ of Table 3 also indicates that the effect of NPL on ECGRWTH has a negative direction (-0.0001) and is not significant (0.5781). This means that financial system stability which is proxy by NPL has a negative and insignificant impact on sustainable economic growth. This is possible because there are other factors that affect sustainable economic growth, such as a growth income per capita, inflation, and others. 
Table 3. Research Results

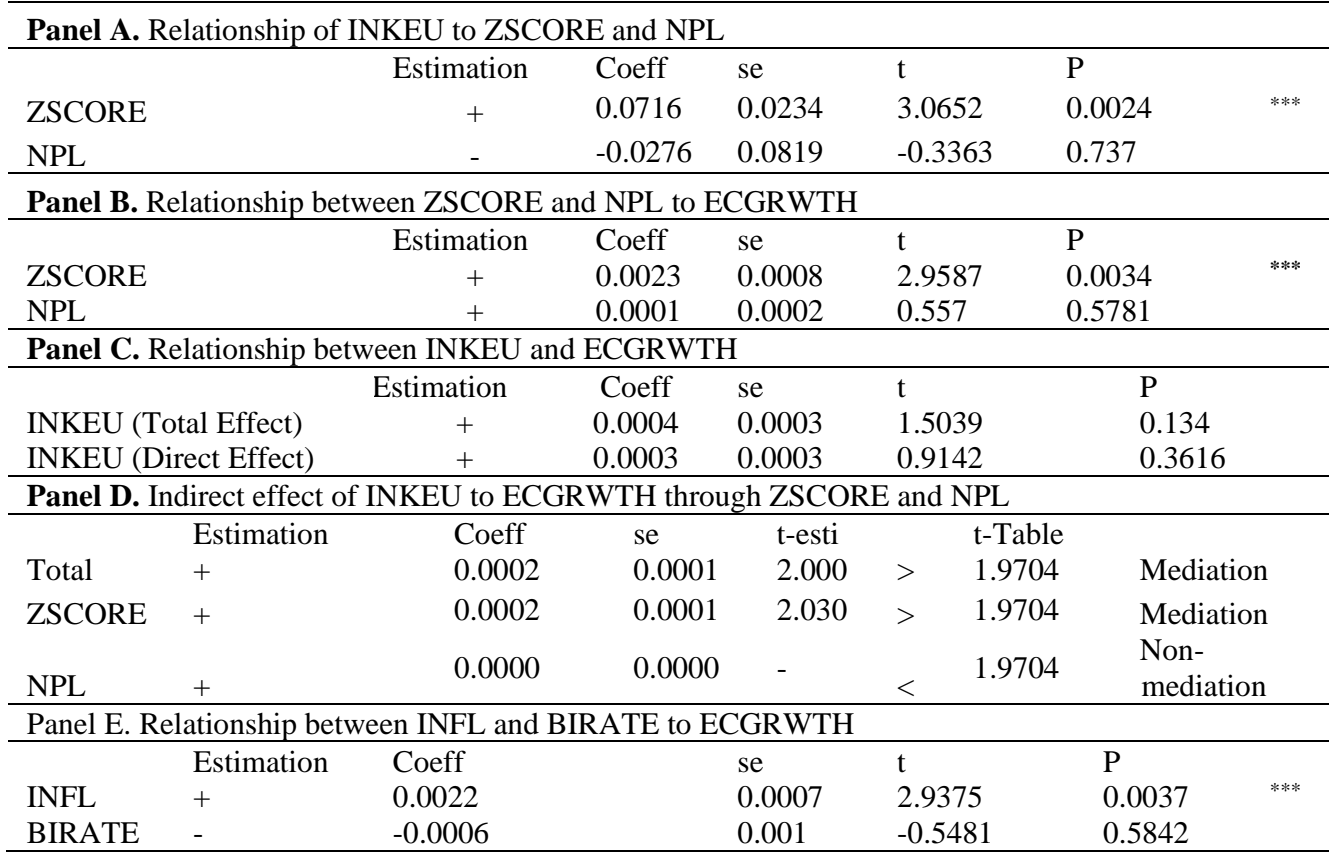

Note: Significant at the $10 \%, 5 \%$ and $1 \%$ levels is shown by $*), * *), * * *)$.

Panel $\mathrm{C}$ of Table 3 explains the impact of financial inclusion (INKEU) on sustainable economic growth (ECGRWTH). The total effect and direct effect of INKEU on ECGRWTH have a positive direction (0.0004 and 0.0003), but both are not significant $(0.1340$ and 0.3616$)$. Hypothesis 1 that states that financial inclusion does not impact sustainable economic growth is accepted. The results are consistent with the findings of Okoye et al. (2017), Gour`ene and Mendy (2017), and Nkwede (2015). This is likely due to the unavailability of banking and financial services, the absence of entree to banking or financial facilities and the minimum utilization of banking or financial services in Indonesia, especially in rural and isolated areas.

Panel D of Table 3 shows the indirect impact of financial inclusion (INKEU) on sustainable economic growth (ECGRWTH) through financial system stability (ZSCORE and NPL). The indirect effect of INKEU on ECGRWTH through ZSCORE has a t-statistic of 2.0382 greater than t-table of 1.9704. This means that financial inclusion affects sustainable economic growth through a stable financial system which is measured by ZSCORE. Accordingly, hypothesis 2(a) which states that financial inclusion influences sustainable economic growth through financial system stability which is measured for ZSCORE is accepted. Thus, it can be concluded that hypothesis 2 which confirms that financial system stability mediates the effect of financial inclusion on sustainable economic growth is accepted. When the financial system is unstable and does not function efficiently, the allocation of funds is not going well so that it can hamper sustainable economic growth. 
Furthermore, Panel D of Table 3 also shows that the indirect effect of INKEU on ECGRWTH through NPL has a t-statistic of -0.1443 smaller than t-table of -1.9704 . This means that financial inclusion does not affect sustainable economic growth through financial system stability which is measured by NPL. Therefore, hypothesis 2(b) which states that financial inclusion influences sustainable economic growth through financial system stability which is measured by non-performing loans is rejected. Banks with high levels of bad loans raise expectations about the stability of the banking system which is deteriorating. It creates a systemic risk which in turn can lead to the withdrawal of deposits and reducing the power of bank intermediation.

Panel E of Table 3 reveals the effect of control variables (INFL and BIRATE) on sustainable economic growth (ECGRWTH). The effect of INFL on ECGRWTH has a positive direction (0.0022) with a significance level of $1 \%(0.0037)$, while the effect of BIRATE on ECGRWTH has a negative direction (-0.0006) and is not significant (0.5842). It means that inflation affects sustainable economic growth, while the BI rate does not affect sustainable economic growth. High inflation causes people to reduce savings or investment. It affects the operational ability of the banking sector in channeling financing. The same thing happened to the ability of the customer to return the loan. When the solvency and liquidity of the bank decrease it will cause a crisis and bankruptcy of the bank, which results in financial system instability.

\section{Conclusions}

Based on the results, the conclusions can be ascended as follows: (a) Financial inclusion does not affect sustainable economic growth; (b) Financial system stability mediates the effect of financial inclusion on sustainable economic growth. This research has implications for regulators. It requires the efforts of various related parties such as the government, Central Bank, and financial institutions to work together to focus on increasing financial inclusion in Indonesia. Policymakers and regulations need to encourage financial stability through increased diversification of deposits and credit, easy access to open accounts, affordability of costs, distance traveled, and financial literacy are also needed to reach out the low-income groups in reducing risk during financial pressures.

\section{References:}

Aduda, J., Kalunda, E. 2012. Financial Inclusion and Financial Sector Stability With Reference To Kenya: A Review of Literature. Journal of Applied Finance \& Banking, 2(6), 95-120.

Allen, F., Demirguc-Kunt, A., Klapper, L., Soleda, M., Peria, M. 2016. The foundations of Financial Inclusion: Understanding Ownership and Use of Formal Accounts. Journal of Financial Intermediation, 27, 10-30.

Amatus, H., Alireza, N. 2015. Financial Inclusion and Financial Stability in Sub-Saharan Africa (SSA). The International Journal in Social Science, 36(1), 39-49. 
Financial Inclusion, Financial Stability and Sustainability in the Banking Sector:

The Case of Indonesia

Bank Indonesia. 2014. Booklet Keuangan Inklusi. Departemen Pengembangan Akses Keuangan dan UMKM, Bank Indonesia.

Baroroh, U. 2012. Analisis Sektor Keuangan Terhadap Pertumbuhan Ekonomi Regional di Wilayah Jawa: Pendekatan Model Levine. Jurnal Etikonomi, 11(2), 180-215.

Chen, F.W., Feng, Y., Wang, W. 2018. Impacts of Financial Inclusion on Non-Performing Loans of Commercial Banks: Evidence from China. Sustainability, 10(3084), 1-28.

Creel, J., Hubert, P., Labondance, F. 2013. Financial Stabiity and Economic Growth. Working Paper, OFCE-Sciences Po.

Dienillah, A.A., Anggraeni, L. 2016. Dampak Inklusi Keuangan Terhadap Stabilitas Sistem Keuangan di Indonesia. Buletin Ekonomi Moneter dan Perbankan, 18(4), 409-430.

European Central Bank. 2012. Financial stability review. Germany: European Central Bank. Retrieved from http://www.ecb.europa.eu

Gour`ene, G.A., Mendy, P. 2017. Financial Inclusion and Economic Growth in WAEMU: A Multiscale Heterogeneity Panel Causality Approach. Munich Personal RePEc Archive (MPRA). Retrieved from https://mpra.ub.uni-muenchen.de/82251/

Hannig, A., Jansen, S. 2010. Financial Inclusion and Financial Stability: Current Policy Issues. Tokyo, Asian Development Bank Institute. Retrieved from http://www. adbi.org/workingpaper/2010/12/21/4272.financial.inclusion.stability.policy.issues/

Manu, L.P., Adjasi, C.K., Abor, J., Harvey, S.K. 2011. Financial stability and Economic Growth: a Cross-Country Study. International Journal Financial Services Management, 5(2), 121-138.

Morgan, P.J., Pontines, V. 2014. Financial Stability and Financial Inclusion. Tokyo, Asian Development Bank Institute.

Nkwede, F. 2015. Financial Inclusion and Economic Growth in Africa: Insight from Nigeria. Australian Journal of Business Science Design \& Literature, 8(1), 71-82.

Okoye, L.U., Adetiloye, K.A., Erin, O., Modebe, N.J. 2017. Financial Inclusion as a Strategy for Enhanced Economic Growth and Development. Journal of Internet Banking and Commerce, 22(S8), 1-14.

Operaña, B.V. 2016. Financial Inclusion and Financial Stability in the Philippines. Research Paper, Graduate School of Public Policy (GraSPP), The University of Tokyo, Japan, $1-33$.

Preacher, K.J., Hayes, A.F. 2008. Contemporary Approaches to Assessing Mediation in Communication Research. In A.F. Hayes, M.D. Slater, L.B. Snyder (Eds.), The Sage Sourcebook of Advanced Data Analysis Methods for Communication Research, 1354. Thousand Oaks, CA, Sage Publications, Inc.

Rupeika-Apoga, R., Saksonova, S. 2018. SMEs' Alternative Financing: The Case of Latvia. European Research Studies Journal, 21(3), 43-52, DOI: 10.35808/ersj/1042.

Rupeika-Apoga, R., Zaidi, H.S., Thalassinos, E.Y., Thalassinos, I.E. 2018. Bank Stability: The Case of Nordic and Non-Nordic Banks in Latvia. International Journal of Economics and Business Administration, 6(2), 39-55.

Setiawan, S.R. 2017. Ekonomi/Keuangan, online. (E. Djumena, Editor) Retrieved from Kompas.Com: https://ekonomi.kompas.com

Solovjova, I., Rupeika-Apoga, R., Romanova, I. 2018. Competitiveness Enhancement of International Financial Centres. European Research Studies Journal, 21(1), 5-17, DOI: 10.35808/ersj/925.

Williams, H.T., Adegoke, A.J., Dare, A. 2017. Role of Financial Inclusion in Economic Growth and Poverty Reduction in a Developing Economy. Internal Journal of Research in Economics and Social Sciences (IJRESS), 7(5), 265-271. 